\title{
A new genus and species of the family Ectinosomatidae (Crustacea : Copepoda : Harpacticoida) from the groundwaters of India
}

\author{
T. Karanovic ${ }^{1}$ \\ G.L. Pesce ${ }^{2}$
}

Keywords : Copepoda, Ectinosomatidae, Rangabradya, India, taxonomy.

Rangabradya n. gen. and Rangabradya indica $\mathrm{n}$. sp. from the subterranean freshwaters of India are described. The new genus belongs to a group of genera in the family Ectinosomatidae Sars, 1904 possessing fusiform body shape and it is very similar to the genus Halectinosoma Lang, 1944. The new genus has the exopodite and basiendopodite of the fifth leg completely fused, without surface seta, as well as a characteristic appearance of the antennula, antenna and maxilla. The position of the genus Rangabradya n.gen. within the family Ectinosomatidae is discussed.

Un nouveau genre de la famille Ectinosomatidae (Crustacea : Copepoda : Harpacticoida) des eaux souterraines de l'Inde

Mots-clés : Copepoda, Ectinosomatidae, Rangabradya, Inde, taxonomie.

Rangabradya n. gen. et Rangabradya indica n.sp. trouvés dans les eaux douces souterraines de l'Inde sont décrits. Le nouveau genre appartient au groupe des genres de la famille des Ectinosomatidae Sars, 1904 qui ont un corps fusiforme et il est très. proche du genre Halectinosoma Lang, 1944. Le nouveau genre possède les exopodite et baséoendopodite de la cinquième patte complètement soudés et dépourvus de soie accessoire. Les antennules, antennes et maxilles sont très caractéristiques. La position du genre Rangabradya n. gen. dans la famille Ectinosomatidae est discutée.

\section{Introduction}

The family Ectinosomidae was established by Sars (1904) and later discussed in a very detailed manner by Olofsson (1917), who also provided a key to the five genera known at that time. The family name was corrected to Ectinosomatidae by Moore (1978), according to the International Code of Zoological Nomenclature. Further systematic changes at the family level were made by Lang $(1944,1948,1965)$. He also provided very useful keys to genera, 10 in 1948 and 14 in 1965. The family Ectinosomatidae presently encompasses about 232 species and subspecies, classified into 19 valid genera (Bodin 1997) : Arenosetella Wilson, 1932 ; Bradya Boeck, 1972 ; Bradyellopsis Brian,

\footnotetext{
1. Western Australian Museum, Francis Street, Perth, W.A. 6000, Australia.

2. Dipartimento di Scienze Ambientali, Universita di L'Aquila, Via Vetoio 14, 67100 L'Aquila, Italy.
}

1924 ; Ectinosoma Boeck, 1865 ; Halectinosoma Lang, 1944 ; Halophytophilus Brian, 1917 ; Hastigerella Nicholls, 1935 ; Klieosoma Hicks \& Schriever, 1985 ; Lineosoma Wells, 1965 ; Microsetella Brady \& Robertson, 1873 ; Noodtiella Wells, 1965 ; Pseudectinosoma Kunz, 1935 ; Pseudobradya Sars, 1904 ; Sigmatidium Giesbrecht, 1881 ; Ectinosomella Sars, 1910 ; Ectinosomoides Nicholls, 1945 ; Oikopus Wells, 1967 ; Peltobradya Médioni \& Soyer, 1967 ; and Tetanopsis Brady, 1910. Last five genera are monospecific, and the genus Bradya is subdivided into two subgenera : Bradya s. str. and Parabradya Lang, 1944. Only the genus Pseudectinosoma is predominantly freshwater. All of the others are marine genera, some of which contain a few freshwater species. Lang (1965) noted two distinct lines of evolution within the family Ectinosomatidae : one which comprises genera with a rectangular cephalothorax and linear body shape, and other with a cephalothorax gradually attenuated anteriorly and fusiform body shape.

The genus Halectinosoma is the largest in the fami$1 y$, currently encompassing 57 valid species. Initially it 
was established as a subgenus of the genus Ectinoso$m a$, with the following short diagnosis (Lang 1944) : "Exp. P.5 mit 3 Rand- und 1 Flachenborste, welch letztere evtl. fehlen kann." Exactly the same was repeated later (Lang 1948), but unfortunately Lang also this time omitted to designate the type species. This was done by Vervoort (1962), who designated Ectinosoma sarsi Boeck, 1872. Lang (1965) elevated Halectinoso$m a$ to the generic level, although he did not mention Vervoort's designation of the type species. Unfortunately Halectinosoma sarsi (Boeck 1972) was placed as incertae sedis by Clément \& Moore (1995), so the genus is now without a recognizable type species. Lang's $(1944,1948)$ division of Halectinosoma into the "sar$s i$-group (where the third exopodite segment of the second, third and fourth swimming legs bear 3 outer spines) and the "curticorne"-group (where the third exopodite segment of at least the fourth swimming leg bears 2 outer spines) was later (Lang 1965) considered unworkable. Although the detailed morphology is quite conservative within the genus, some of its species have obviously been misplaced and should be referred to other genera. One of them, $H$. porosum Wells, 1967, was formally transfered to the genus Ectinosoma by Huys \& Bodin (1997). Some others probably belong to undescribed genera, which we will discuss later. However, the systematic of the genus Halectinosoma is problematic and species identification is very difficult due to the inadequacy of most of the descriptions in the literature (Clément \& Moore 1995). This genus is indeed much closer to the genus Pseudobradya than to Ectinosoma, from which it was segregated. One of the characters that is traditionally used to distinguish $\mathrm{Ha}$ lectinosoma from Pseudobradya is the condensed maxillary endopodite in the former (Huys \& Bodin 1997). Also, the position of the inner setae on the maxillary basis can be used as a very good distinguishing character between these two genera (they are always situated near the top of the basis in Pseudobradya). Probably the subgeneric status of Halectinosoma (of the genus Pseudobradya) would be more appropriate, but the entire generic complex is in need of revision which is beyond the scope of this paper.

We had an opportunity to examine material collected from a freshwater well in India and kindly placed at our disposal by Dr Ranga Reddy (Nagarjuna University). This material is especially similar to some species of Halectinosoma with dubious taxonomic status and displaying some unusual character reductions. However, after detailed examination it was clear that the material from India cannot be placed within the genus Halectinosoma and we describe it here as a new genus and new species, Rangabradya indica. At present no other known species of the family Ectinosomatidae can be placed into the new genus with certainty.

\section{Methods}

The sample was taken with a plankton net (mesh size $0.07 \mathrm{~mm}$ ), by filtering the groundwater for about eight hours, and fixed in $5 \%$ formaldehyde. Copepods were separated and transferred to $70 \%$ ethanol. Specimens were dissected in Faure's medium, which was prepared following the procedure discussed by Stock \& Vaupel Klein (1996). Dissected appendages were covered with a coverslip. For the urosome or the whole animal two human hairs were mounted between the slide and coverslip, so the parts could not be squashed. By moving the coverslip carefully by hand, the whole animal or a particular appendage could be positioned in different aspects, making possible the observation of morphological details. During the examination water slowly evaporated, and appendages or whole animals eventually remained in completely dry Faure's medium. All drawings were prepared using a drawing attachment (tube) on a Leica-DMLS brightfield compound microscope, with C-PLAN achromatic objectives. Specimens which were not drawn were examined in a mixture of equal parts of distilled water and glycerol and, after examination, were again preserved in $70 \%$ ethanol.

\section{Description}

Order : Harpacticoida Sars, 1903

Family : Ectinosomatidae Sars, 1904

\section{Genus : Rangabradya n. gen.}

\section{Diagnosis}

Small Ectinosomatidae with fusiform habitus. Surface of body somites with numerous small pores and some sensillae. Rostrum broadly rounded. Female genital double-somite without any trace of subdivision. Posterior edge of furcal rami dorsally and ventrally terminating as acuminate lappets. Female antennula 5segmented, short ; third segment longest. Antenna with 3-segmented exopodite ; first segment smooth, second armed with 1 lateral seta, third segment bearing 1 subapical seta and 1 very strong spine, almost as broad as segment. Mandibula with 2 very strong spines at ventral base of pars incisiva ; exopodite small, armed with only 2 setae. Maxillula with highly mobile arthrite of precoxa ; coxa, basis and endopodite completely fused ; endopodite apically bearing 3 setae. 
Maxilla with elongate syncoxa ; proximal endite situated at first half ; basis as long as syncoxa, armed with 2 setae on about middle of inner edge ; endopodite condensed, bearing 2 stout geniculate setae. Maxilliped 3-segmented ; first segment short, armed with 1 very long seta ; second segment twice as long as wide, unarmed ; third segment as long as first one, armed with 3 setae, apicalmost of which shortest. All swimming legs with 3-segmented exopodites and endopodites ; endopodites somewhat longer and stouter than exopodites, but first endopodite and first exopodite segments of almost equal length. Setae on exopodites and endopodites very stout, mostly smooth. Armature formula of third exopodite segments, from first to fourth swimming legs : 5.6.6.6. Fifth leg with completely fused basiendopodite and exopodite ; exopodite without surface seta and with 3 apical setae, outermost of which longest ; inner expansion of basiendopodite bearing 2 short and stout setae in female, only 1 short seta in male. Male sixth leg consisting of small triangular, distinct, chitinous plate, lacking armature and ornamentation but with serrated hind margin.

Type species : Rangabradya indica $\mathrm{n}$. sp.

\section{Etymology}

The genus is named in honour of Dr Ranga Reddy from the Nagarjuna University, who sent us this interesting material for determination ; prefixed to the genus name Bradya. Gender feminine.

\section{Rangabradya indica n.sp.}

(Figs. 1-28)

\section{Material examined}

Holotype (female), allotype (male) and 36 paratypes ( 1 male, 21 females and 14 copepodids), from a freshwater bore-well (depth c. $50 \mathrm{~m}$ ) in Brindavan Gardens, Guntur town $\left(16^{\circ} 18^{\prime} \mathrm{N}-80^{\circ} 29^{\prime} \mathrm{E}\right)$, southern India, 06 December 1999 , collected by Dr Ranga Reddy. The water was clear and calcareous (calcium carbonate flakes observed on the bottom of overhead storage tank) ; temperature $28^{\circ} \mathrm{C}$. Holotype, allotype and $4 \mathrm{pa-}$ ratype females are completely dissected and mounted on microscope slides in Faure's medium. Another 4 paratypes ( 1 male and 3 females) are preserved as nondissected animals on slides in the same medium. All other paratypes (14 females and 14 copepodids) are preserved in $70 \%$ ethanol. Holotype, allotype, one dissected paratype female and all paratypes preserved in ethanol are deposited at the University of L'Aquila (Dipartimento di Scienze Ambientali). Other 7 paratypes ( 1 male and 6 females) are deposited in the Western Australian Museum, Perth.

\section{Etymology}

The species name is taken from the name of the Republic of India where the material was collected, i.e. as an adjective agreeing in gender with the feminine generic name.

\subsection{Description of female (holotype)}

Body length, excluding furcal setae, $0.374 \mathrm{~mm}$. Habitus fusiform and robust, greatest width at hind margin of cephalothorax ; rostral expansion not visible dorsally. Colour of preserved specimen yellowish. Nauplius eye absent. Rostrum well developed, membranous, broadly rounded, partially fused at base with cephalothorax and furnished with two thin sensillae laterally. Prosome comprising cephalothorax (incorporating first pedigerous somite) and 3 free pedigerous somites. Cephalothorax as long as its basal width and gradually tapering anteriorly; hind margin smooth. Surface of cephalothorax shield with numerous small pores and with several sensillae near hind margin. First and second free pedigerous somites with several pores and sensillae ; hind margins smooth. Last pedigerous somite with row of spinules dorsolaterally, very near to hind margin. Urosome comprising fifth pedigerous somite, genital double-somite (representing fused genital and first abdominal somites) and 3 free abdominal somites. Fifth pedigerous somite (Fig. 3 ) with 2 short rows of thin spinules and 2 pores ventrally, with numerous pores and 2 sensillae dosolaterally, and with row of large spinules close to hind margin. Genital doublesomite about 1.2 times as broad as long ; without any trace of subdivision, with several sensillae and pores and with row of large spinules close to hind margin. Copulatory pore small, just at midlength of genital double-somite (Fig. 3) ; copulatory duct broad, then narrowing ; receptacle very small, just little broader than first part of duct. Fused sixth legs forming simple genital operculum, without any armature or ornamentation (Fig. 3). First free abdominal somite also with several sensillae and pores, and with posterior row of large spinules. Second free abdominal somite without sensillae and spinules, with 2 dorsal and 6 ventral pores ; hind margin forming broadly convex, short, pseudoperculum. Anal somite medially cleft ; with 2 transverse rows of spinules on each side of anal sinus, which visible only from lateral side through cuticle and muscles. Furcal rami slightly divergent, triangular and about 1.7 times as long as greatest width (Fig. 3) ; furnished with 6 setae. Posterior edge of rami terminating dorsally and ventrally as acuminate lappets ; ventral lappet slightly longer than dorsal. Inner apical seta fused with ramus and about half as long as 
outer apical seta, while middle apical seta about twice as long as outer one. Dorsal seta inserted near inner margin, in first half of furcal ramus (Fig. 3). Only 2 lateral setae present, one slightly longer than ventral lappet, other minute. All furcal setae naked. No other somatic ornamentation observed (no additional rows of minute spinules or hairs). Antennula 5-segmented, with 1 slender aesthetasc on apical segment, 1 long aesthetasc on third segment (reaching significantly beyond tip of appendage), and with setal formula as follows : 1.7.9.3.7 (Fig. 2). All setae on antennula naked ; third segment longest one. Antenna comprising small coxa, basis, 2-segmented endopodite and 3-segmented exopodite (Fig. 6). Basis with close set of 3 setules issuing from inner margin. First endopodite segment unarmed and unornamented, while second ornamented with 3 strong spinules at inner proximal corner, with 2 spinules at outer distal corner, and armed with 2 lateral strongly spinulose setae and 5 apical setae, of which only 1 not spinulose (Fig. 6). First exopodite segment smooth ; second with 1 thin inner seta ; third segment longest, armed with 1 subapical pinnate seta and 1 extremely strong apical spine, almost as broad as segment and about twice as long. Exopodite of antenna somewhat shorter and considerably slender than endopodite (Fig. 6). Labrum large, rhomboidal, strongly bulging, but without any beak visible from lateral side. Mandibula with 2 very strong spines at ventral base of bidentate pars incisiva of coxal gnathobase ; lacinia unidentate (Fig. 11). Basis large, unornamented and armed with 3 setae at distal inner corner. Exopodite 1-segmented, small, armed with 1 inner and 1 apical seta. Endopodite of mandibula also 1-segmented, much longer than exopodite ; armed with 1 inner, 1 outer and 3 apical setae (Fig. 10). Maxillula with large praecoxa, arthrite of which highly mobile and armed with 4 unguiform spines (Fig. 15). Coxa, basis and endopodite completely fused (Fig. 14) ; endopodite armed with 1 inner and 3 apical setae ; coxa-basis armed with 3 setae along inner margin. Exopodite of maxillula 1-segmented, small and armed with 2 naked subapical setae (Fig. 14). Maxilla with elongate syncoxa, which bearing 3 endites along inner margin (Fig. 18). Proximal endite situated at first half of syncoxa, armed with 3 strong and 1 thin seta ; middle endite situated just at midlength of syncoxa, armed with
1 strong seta ; distal endite longest, highly mobile, and armed with 2 divergent setae. Basis as long as syncoxa, swelling out inwards, armed with 2 setae about at middle of inner edge. Endopodite condensed, without clear segmentation and armed with 3 normal and 2 thick geniculate setae (Fig. 18). Maxilliped 3-segmented, armed with 1 very long seta on first segment and 3 setae on third segment, of which apical one shortest (Fig. 16). Second segment unarmed, longest (about twice as long as wide) and armed with 1 longitudinal row of spinules. All swimming legs with 3-segmented exopodites and endopodites (Figs. 5, 7, 9 and 13). Swimming legs armature formula as follows (legend : inner/outer spine or seta ; inner/terminal/outer) :

\begin{tabular}{lccclll} 
& \multicolumn{3}{c}{ Exopodite } & \multicolumn{3}{c}{ Endopodite } \\
Segments & 1 & 2 & 3 & 1 & 2 & 3 \\
First leg & $0 / 1$ & $1 / 1$ & $1 / 2 / 2$ & $1 / 0$ & $1 / 0$ & $2 / 2 / 1$ \\
Second leg & $1 / 1$ & $1 / 1$ & $2 / 2 / 2$ & $1 / 0$ & $1 / 0$ & $2 / 2 / 1$ \\
Third leg & $1 / 1$ & $1 / 1$ & $2 / 2 / 2$ & $1 / 0$ & $1 / 0$ & $2 / 2 / 1$ \\
Fourth leg & $1 / 1$ & $1 / 1$ & $2 / 2 / 2$ & $1 / 0$ & $1 / 0$ & $2 / 2 / 1$
\end{tabular}

Endopodites somewhat longer and stouter than exopodites, but first endopodite and first exopodite segments of almost equal length. Outer margins of almost all endopodite and exopodite segments ornamented with large spinules, as well as distal margins of first and second segments (Figs 5, 7,9 and 13). Armature of exopodites and endopodites very stout, mostly smooth ; only outer spines pinnate on outer margin. Basis of first swimming leg with slender outer seta, with stout spine on distal inner corner and row of large spinules at its base (Fig. 4). Coxa of first swimming leg without surface ornamentation. Basis of second, third and fourth swimming legs with slender outer seta (each with a few spinules around base), and with small and obtuse process on distal inner corner ; coxae of these legs each with row of spinules near distal margin (Figs 7,9 and 13). Couplers (intercoxal sclerites) of all swimming legs concave, elongate, and without surface ornamentation. Fifth leg with completely fused basiendopodite and exopodite, and without surface armature or ornamentation, except 1 small pore near proximal outer corner (Fig. 3). All setae short and stout, except outer basipodite seta which slender. Inner basiendopodite seta stouter and longer than outer one. Inner exo-

Figs 1-5. Rangabradya indica n. gen., n. sp., 1, paratype (female $0.392 \mathrm{~mm}$ ) ; 2-5, holotype (female $0.374 \mathrm{~mm}$ ) : 1 - habitus, dorsal view ; 2 - antennula ; 3 - urosome, ventral view ; 4 - coxa and basis of first swimming leg ; 5 - first swimming leg. Scales $=0.1 \mathrm{~mm}$.

Figs. 1-5. Rangabradya indica n. gen. n. sp., 1, paratype (femelle 0,392 mm) ; 2-5, holotype (femelle 0,374 mm) : 1 - corps, vue dorsale ; 2 - antennule ; 3 - urosome, vue ventrale ; 4 - coxa et basis de la première patte natatoire ; 5 - première patte natatoire. Echelles $=0,1 \mathrm{~mm}$. 


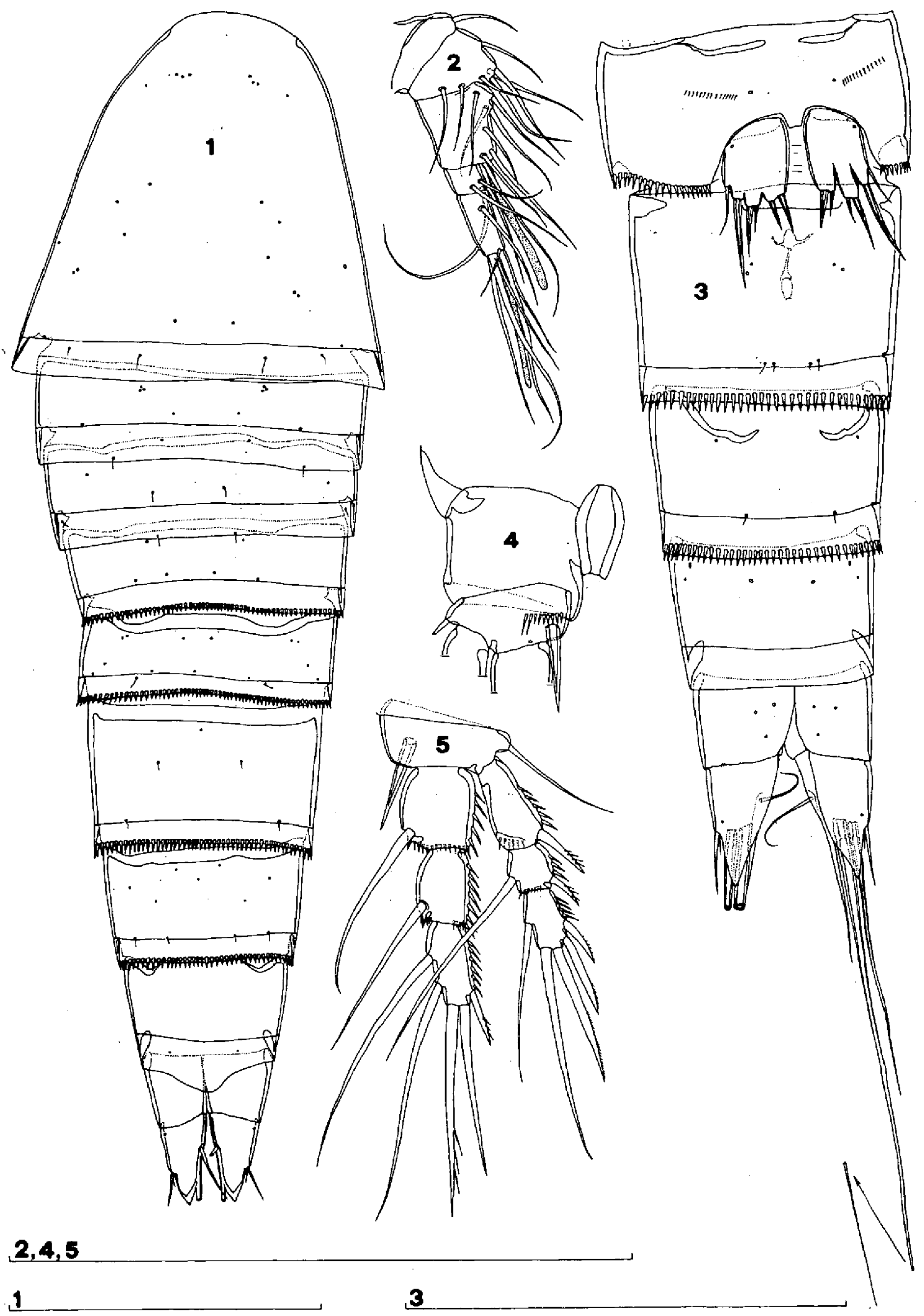


podite seta about as long as outer basiendopodite one, while middle exopodite seta somewhat longer than inner basiendopodite one. Outer exopodite seta longest and strongest one (Fig. 3), reaching just to midlength of genital double-somite.

\subsection{Description of male (allotype)}

Body length $0.342 \mathrm{~mm}$. Habitus similar to female, just more slender. Second free pedigerous somite with finely serrated hind margin. Urosome comprising fifth pedigerous somite, genital somite and 4 abdominal somites. Ornamentation of urosomal somites, as well as furcal rami shape similar to female (Figs. 23 and 24). Single, completely formed, horizontally-placed spermatophore visible inside genital somite (Fig. 24). Antennula strongly geniculate, without clear distinction between segments, and also with hardly visible insertions of some setae (Fig. 22). Rostrum (Fig. 26), antenna, labrum, mandibula, maxilla, maxilliped and swimming legs very similar to those of female. Fifth leg simple plate, as in female, but much shorter (about twice as broad as long) and with only 1 short seta on inner expansion of basiendopodite (Fig. 27). Sixth leg consisting of small, triangular, distinct chitinous plate, without any armature or ornamentation and with serrated hind margin (Fig. 24).

\section{Variability}

Thirty-eight specimens ( 24 adults) of Rangabradya indica from the type locality were found and examined. All specimens are very similar in the most morphological characteristics. Body lengths of females range from $0.336 \mathrm{~mm}$ to $0.406 \mathrm{~mm}(0.365 \mathrm{~mm}$ average $; \mathrm{n}=22$ ), while in males they range from $0.342 \mathrm{~mm}$ to $0.353 \mathrm{~mm}(0.348 \mathrm{~mm}$ average $; n=2)$. The lobes on the exopodite of the fifth leg in females can be more or less visible (Fig. 3), but usually they are not visible (Fig. 19). The exopodite of the left fifth leg in one paratype female has a reduced inner apical seta (Fig. 20), while the right fifth leg is normally built. The sixth legs in the allotype male, as well as in the paratype male, are slightly asymmetrical (Fig. 24), and their hind margins are differently serrated (Figs 24 and 28). The spermatophore inside the male genital somite can be oriented horizontally or vertically (Figs 21, 24 and 28).

\section{Discussion}

Two morphological characteristics that easily distinguish Rangabradya indica n. sp.from all other Ectinosomatidae species are : only one basiendopodite seta present on the male fifth leg and the shape of the third endopodite segment of the antenna in both sexes. Very strong apical setae on the third exopodite segment of the antenna is also a characteristic of the monospecific genus Peltobradya, but in that genus the setae are almost of equal length. However, there are many other differences between it and Rangabradya. The genus Peltobradya has a 2-segmented endopodite of the first swimming leg, a distinct exopodite of the fifth leg with surface seta present and a very specific body shape, which easily distinguishes it from all other genera in the family (Médioni \& Soyer 1967).

The possession of a fusiform body places Rangabradya in a separate evolutionary line from those genera where the cephalothorax is rectangular and the general body form is cylindrical (viz. Arenosetella, Ectinosomoides, Hastigerella, Lineosoma, Noodtiella, Oikopus and Tetanopsis). By the possession of 3-segmented exopodites and endopodites in all swimming legs, Rangabradya differs from Bradyellopsis, Halophytophilus, Pseudectinosoma and Sigmatidium. The last genus has indeed one species, Sigmatidium triarticulatum Mielke, 1979 from Galapagos (Mielke 1979), with all swimming legs 3-segmented. We completely agree with Galassi et al.(1999) that a revision of the genus Sigmatidium is necessary. Nevertheless, all six species currently considered as members of this genus, have a completely different shape of the maxilla, which is prehensile with short, curved, endopodite setae (Lang 1948, Mielke 1974, 1979, Kunz 1974). Although a relatively close relationship between Rangabradya and Sigmatidium is evident, we believe that the similar shape of the fifth leg (fused exopodite, without surface seta) could be convergent. The monospecific genus Ectinosomella differs from all other ectinosomatid genera by its completely reduced mandibular endopodite and exopodite (Lang 1948, 1965), and from Rangabradya differs also by the shape of maxilla, maxilliped, fifth leg and by the swimming leg armature formula. The genus Klieosoma can be distin-

Figs. 6-8. Rangabradya indica n. gen., n. sp., 6 and 7, holotype (female $0.374 \mathrm{~mm}$ ) ; 8, paratype (female $0.389 \mathrm{~mm}$ ) : 6 - antenna ; 7 - second swimming leg ; 8 - habitus, lateral view. Scales $=0.1 \mathrm{~mm}$.

Figs. 6-8. Rangabradya indica n. gen., n. sp., 6 et 7, holotype (femelle $0,374 \mathrm{~mm}$ ) ; 8 - paratype (femelle $0,389 \mathrm{~mm}$ ) :6 - antenne ; 7 - deuxième patte natatoire ; 8 - corps, vue latérale. Echelles $=0,1 \mathrm{~mm}$. 

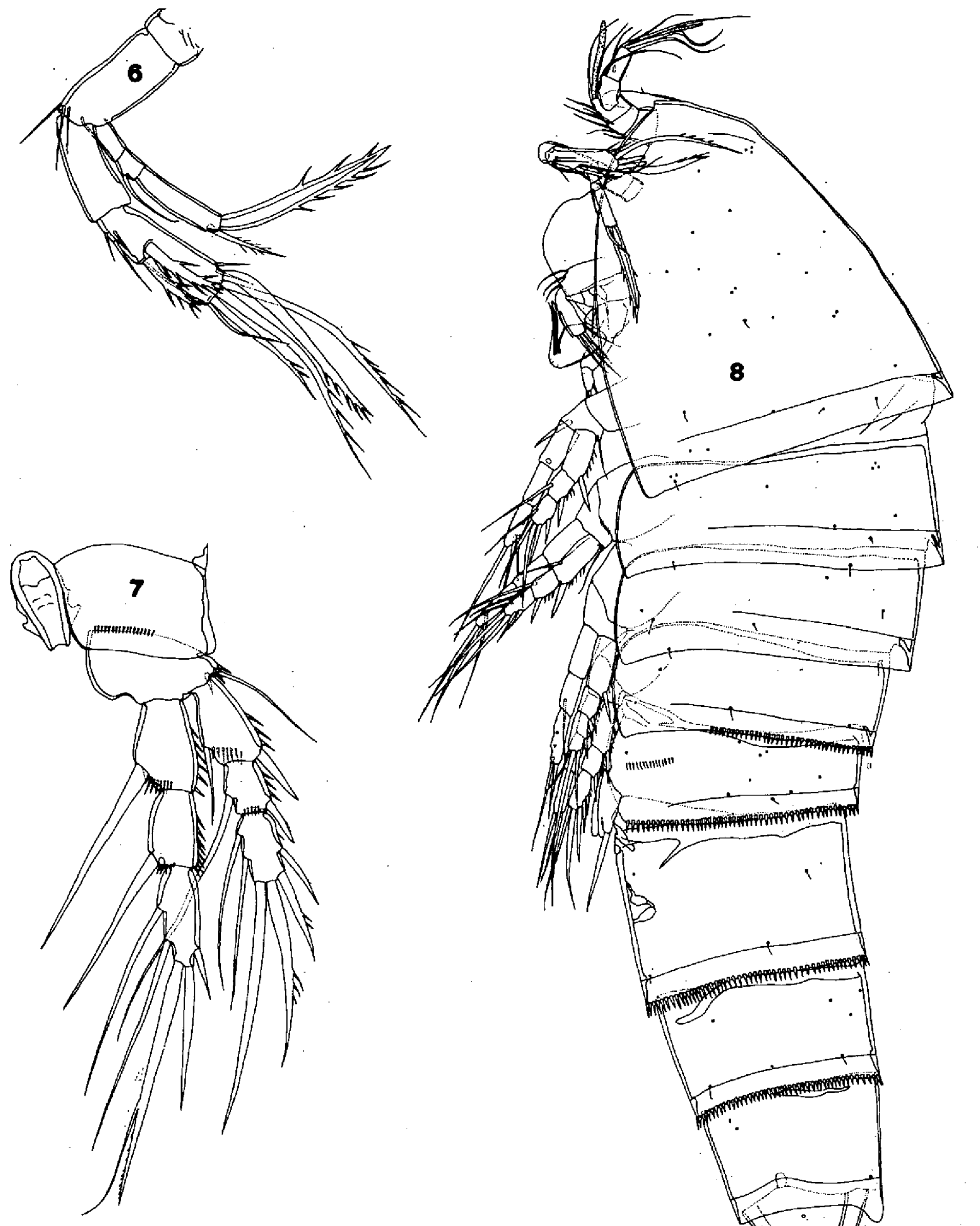

8

6,7 
guished from Rangabradya by the shape of the maxilla (it is very similar to that of the genus Sigmatidium), fifth leg and prehensile endopodite of the first swimming leg, although 3-segmented (Klie 1949, Hicks \& Schriever 1983, 1985).

The new genus belongs to that evolutionary line which encompasses the following 5 genera : Bradya, Ectinosoma, Halectinosoma, Microsetella and Pseudobradya. They all have similar oral appendages, fusiform body shape and all swimming legs with 3-segmented exopodites and endopodites, but which are not prehensile. As stated above, Rangábradya is most similar to the genus Halectinosoma. Four other genera have some very important morphological features which distinguish them from Rangabradya : Bradya has a 2-segmented maxilliped ; Ectinosoma has 4 apical setae on the exopodite of the fifth leg; Microsetel$l a$ has a very elongated antennula; and $P$ seudobradya has a clearly 3-segmented maxillary endopodite, as well as inner setae on the maxillary basis which are always near the top. The genus Microsetella encompasses only two marine pelagic species : $M$. norvegica (Boeck, 1865) and $M$. rosea (Dana, 1848). The latter is known only from females. Males of $M$. norvegica display sexual dimorphism in the fifth leg shape, like Rangabradya indica, but in the first species the male basiendopodite lacks setae and the exopodite bears only one surface and two apical setae (see Olofsson 1917, Wilson 1932, Lang 1948, Chislenko 1967, Ito 1968). In our opinion the nature of sexual dimorphism of the fifth leg in Microsetella and Rangabradya is completely different, and can not be used as evidence of a close relationship. The main differences between Rangabra$d y a$ and the most similar genus Halectinosoma, besides the exopodite of the antenna and the male fifth leg, are as follows :

1) the exopodite of the fifth leg is completely fused with the basiendopodite in Rangabradya, but divided or subdevided in Halectinosoma ;

2) the surface seta on the fifth leg exopodite is absent in Rangabradya, but present in Halectinosoma ;
3) the male sixth leg lacks setae in Rangabradya, but has two setae in Halectinosoma ;

4) the outermost seta on the fifth leg exopodite is the longest in Rangabradya, while in Halectinosoma the median seta is the longest ;

5) the ornamentation of the abdominal somites is reduced in Rangabradya ;

6) the third antennular segment is much longer in Rangabradya than in Halectinosoma ;

7) the maxillary coxa is more elongated in Rangabradya, with the proximal endite in the first half, while in Halectinosoma the proximal endite is near the other two, in the distal part of the coxa ;

8) the armature formula of the third exopodite segments from the first to fourth swimming legs is 5.6.6.6 in Rangabradya, while in Halectinosoma there are usually more spines and setae. It must be pointed out that Halectinosoma abyssicola Bodin, 1968 has the same swimming leg armature formula as Rangabradya indica, but exactly the same formula is also found in Hastigerella antarctica Dahms \& Schminke, 1992 and in Oikopus rostrilabrus Wells, 1967 (see Wells 1967, Bodin 1968, Dahms \& Schminke 1992). Presumably this represents convergence, and this formula can be used as a generic feature only with caution.

Miura (1964) described Ectinosoma japonica from the subterranean freshwaters of Japan, which is currently considered as a member of the genus Halectinosoma (see Lang 1965, Bodin 1997). It lacks surface seta on the fifth leg exopodite. In our opinion, this species needs careful reexamination and, if the original description is correct, it cannot belong to the genus Halectinosoma. The strongly developed anal operculum of the adult male, as it was drawn in the original description, does not conform to the family diagnosis, but if any structure exists on the anal somite it may be of a similar nature to the unguiform or spiniform formations found in the genus Arenosetella. However, $H$. japonica differs from Rangabradya indica in many features and cannot be included in the new genus.

Figs 9-20. Rangabradya indica n. gen., n. sp., 9-11, 13-16 and 18, holotype (female 0.374 mm); 12 and 17, paratype (female 0.357 mm); 19, paratype (female $0.377 \mathrm{~mm}$ ) ; 20, paratype (female $0.354 \mathrm{~mm}$ ) : 9 - third swimming leg ; 10 - mandibula ; 11 - coxal gnathobase of mandibula, semihorizontal ; 12 - coxal gnathobase of mandibula, horizontal view ; 13 - fourth swimming leg ; 14 - maxillula ; 15 - arthrite of precoxa of maxillula ; 16 -maxilliped ; 17 - third segment of maxilliped ; 18 - maxilla ; 19 - fifth leg ; 20 - fifth leg. Scale $=0.1 \mathrm{~mm}$.

Figs. 9-20. Rangabradya indica n. gen., n. sp., 9-11, 13-16 et 18, holotype (femelle 0,374 mm); 12 et 17, paratype (femelle 0,357 mm) ; 19, paratype (femelle $0,377 \mathrm{~mm}$ ) ; 20, paratype (femelle $0,354 \mathrm{~mm}$ ) : 9 - troisième patte natatoire ; 10 - mandibule ; 11 - coxa de la mandibule, vue semihorizontale ; 12 - coxa de la mandibule, vue horizontale ; 13 - quatrième patte natatoire ; 14 - maxillule ; 15 - arthrite de la précoxa de la maxillule ; 16 - maxillipède ; 17 - troisième segment de la maxillipède ; 18 - maxille ; 19 - cinquième patte ; 20 - cinquième patte. Echelle = $0,1 \mathrm{~mm}$. 

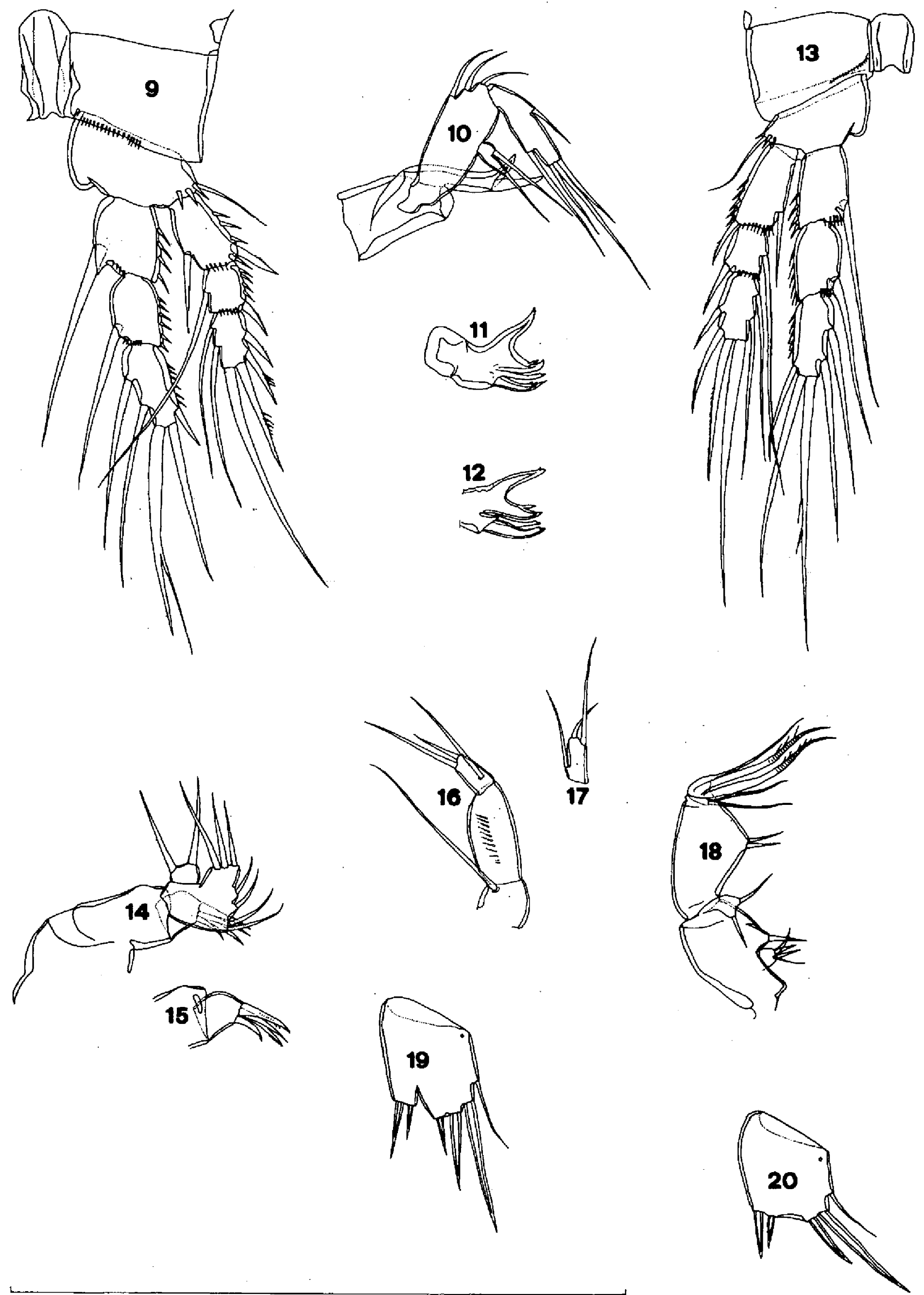
Another species, Halectinosoma uniarticulatum, described from the subterranean freshwaters of central Asia by Borutzky (1972), seems to be much closer to $R$. indica. Describing it, Borutzky (1972) quoted (translation): "By the shape of oral appendages this new species should be considered as a member of the genus Halectinosoma, no matter for its 1-segmented fifth leg which distinguishes it from all the other species of that genus." However, the shape of maxilla, as drawn by Borutzky, is quite different from that found in the genus Halectinosoma (as well as in Rangabra$d y a$ ) and we would not be surprised if detailed reexamination of this species shows a close relationship with the genus Hastigerella. The armature formula of third exopodite segment, from the first to fourth swimming legs, is 5.5.5.4 in "Halectinosoma" uniarticulatum, and third endopodite segment of the fourth swimming leg bears only three setae. We cannot place this species in any of the ectinosomatid genera without careful reexamination. A completely fused exopodite of the fifth leg without surface seta is also characteristic of Arenosetella unisetosa, which was described from females only by Wells (1965) from the Scottish marine sublittoral zone. It is currently considered (Bodin 1997) a member of the genus Hastigerella, but because the oral appendages of this species were not described, it is very difficult to classify it. Wells (1965) was doubtful about its position and also stated that the body shape is fusiform ("... more like the condition in $E c$ tinosoma"), which means that it is impossible to retain this species in the genus Hastigerella. It is also impossible to include this species in the genus Rangabradya without detailed reexamination and redescription of all morphological features. The female fifth leg is similar to that of $R$. indica, but there are some significant differences : the outermost exopodite seta is the shortest one ; the shape of unique fifth leg plate is triangular ; and the fused exopodite is clearly trilobate in "Hastigerella" unisetosa. Two species of the genus Halectinosoma were considered to lack the surface seta on the fifth leg exopodite : $H$. crystalli (T. Scott, 1893) and $H$. littoralis (Nicholls 1940) (see Nicholls 1940, Lang
$1948,1965)$. Indeed Lang (1948, p. 210, fig. 116/10) drew the fifth leg of $H$. tenerum without surface seta, but in the description he quoted "die Flachenborste sitzt mitten zwischen diesem Absatz und der Basis des Gliedes", as it was stated in the original description of this species (Sars 1920). Reexamination of the syntypes of $H$. chrystalli by Clément \& Moore (1995) confirmed the presence of a surface seta at the base of the fifth leg exopodite. We also believe that $H$. littoralis has a surface seta, because all other details of its morphology are very similar to the other species of the genus. Not that we doubt Nicholls' (1940) interpretation, but it is possible that this seta simply fell off during dissection of the animal.

The outermost apical seta of the fifth leg exopodite being the longest one is a feature, besides Rangabra$d y a$, of the following three genera : Arenosetella, Lineosoma and Noodtiella. We believe that Rangabradya represents one of the transitional stages between the most primitive forms in the family (Pseudobradya, Halectinosoma) and these three very specialized genera with linear body shape. It survived in the freshwater interstitial zone, which was possibly a less competitive environment than the marine interstitial zone (because most of the representatives of the family and possible competitors are and were marine animals), but retained its fusiform body shape. As we have already pointed out, only the genus Pseudectinosoma predominantly inhabits freshwater ecosystems. From all other genera of the family only four species can be found in the freshwater environment : Arenosetella limnophila Sterba, 1967 ; Halectinosoma abrau (Kritschagin, 1877) ; "Halectinosoma" japonica (Miura, 1964); and "Halectinosoma" uniarticulatum Borutzky, 1972 (see Rouch 1969).

Only two males of Rangabradya indica were found, along with 22 females. This represents a male occurrence of $8.3 \%$, but in many ectinosomatid species this rate can be much lower, down to $0.13 \%$ (Marcus 1967). Because of their scarcity, the males of many ectinosomatid species are unknown, which makes taxonomic studies in this family more difficult.

Figs. 21-28. Rangabradya indica $\mathrm{n}$. gen., n. sp., 21, 25 and 28, paratype (male $0.353 \mathrm{~mm}$ ) ; 22-24, 26 and 27 , allotype (male $0.342 \mathrm{~mm}$ ) : 21 - habitus, dorsal view ; 22 - antennula ; 23 - last two abdominal somites and furcal rami, dorsal view ; 24 - first four urosomal somites, semiventral view ; 25 - labrum, ventral view ; 26 - rostrum ; 27 - fifth leg ; 28 - fifth leg, sixth leg and spermatophore. Scales $=0.1 \mathrm{~mm}$.

Figs. 21-28. Rangabradya indica n. gen, n. sp., 21, 25 et 28 , paratype (mâle $0,353 \mathrm{~mm}$ ) ;22-24, 26 et 27 , allotype (mâle 0,342 ) :21 - corps, vue dorsale ; 22 - antennule ; 23 - abdomen, vue dorsale ; 24 - urosome, vue semiventrale ; 25 - labre, vue ventrale ; 26 - rostre ; 27 - cinquième patte ; 28 - cinquième patte, sixième patte et spermatophore. Echelles $=0,1 \mathrm{~mm}$. 

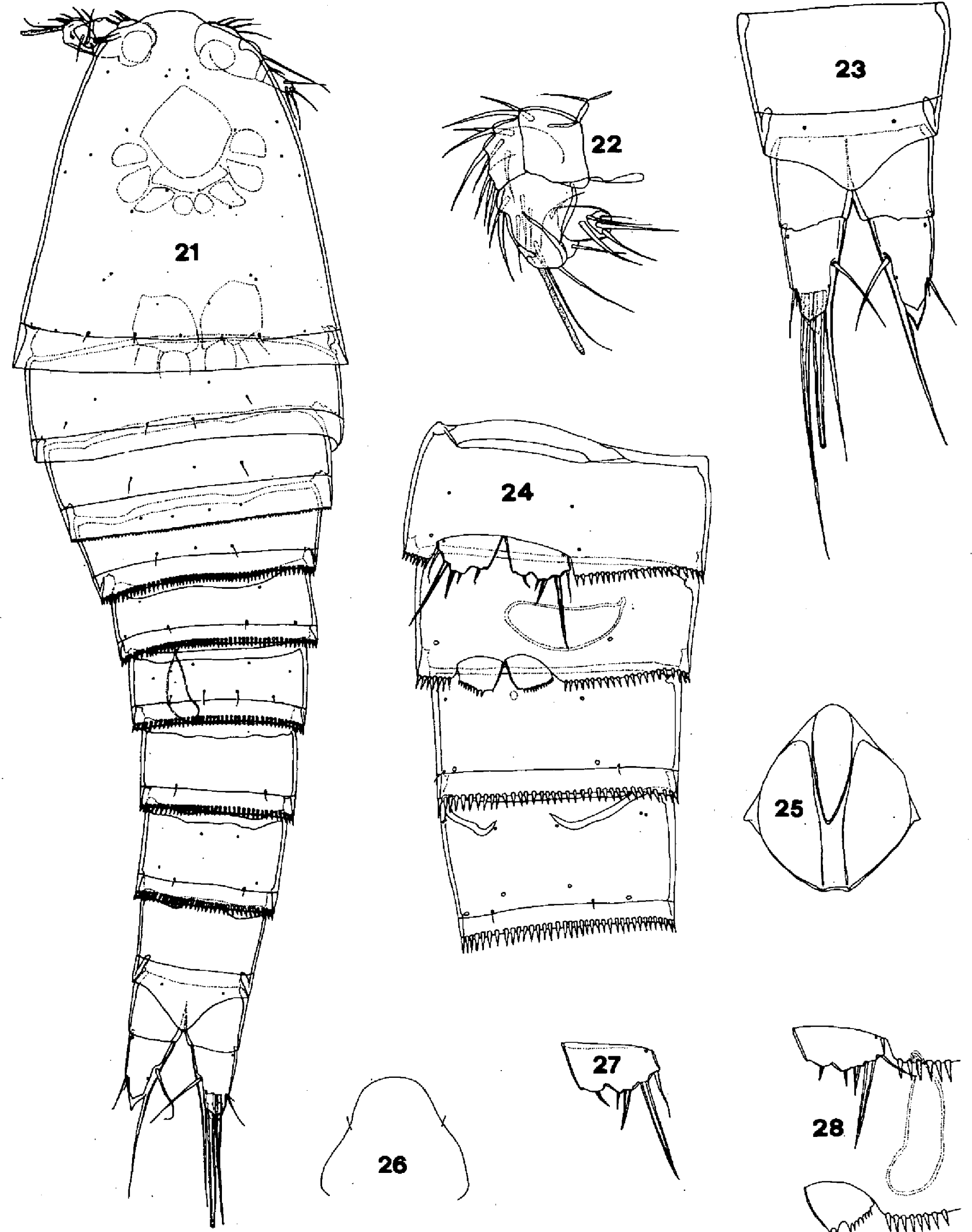

$22,23,25-28$ 


\section{References}

Bodin P. 1968. - Copépodes Harpacticoides des étages bathyal et abyssal du golfe de Gascogne. Mém. Mus. natn. Hist. nat., serie A, 55 (1) : 1-107.

Bodin P. 1997. - Catalogue of the new marine Harpacticoid Copepods (1997 Edition). Doc, trav. Inst. r. Sci. nat. Belg., 89 : 1-304.

Borutzky E.V. 1972. - Copepoda Harpacticoida gruntovyh vod poberezhia oz. Issyk-Kul i iuzhnoi chast Kyzylkumov. Trudy Zool. Inst. Leningrad, 51 : 98-119.

Chislenko L.L. 1967. - Garpakticidy (Copepoda Harpacticoida) Karelskogo poberezhia Belogo moria. Raboty Belomorsk. Biol. Stac. Zool. Inst. AN SSSR, 7 (15) : 48-196.

Clément M. \& Moore C.G. 1995. - A revision of the genus Halectinosoma (Harpacticoida : Ectinosomatidae) : a reappraisal of $H$. sarsi (Boeck) and related species. Zool. J. linn. Soc., 114 : 247-306.

Dahms H.-U. \& Schminke H.K. 1992. — Sea ice inhabiting Harpacticoida (Crustacea, Copepoda) of the Weddell Sea (Antarctica). Bul. Inst. r. Sci. nat Belg., Biol., 62 : 91-123.

Galassi D.M.P., Dole-Olivier M.-J. \& Laurentiis P. de 1999. - Phylogeny and biogeography of the genus Pseudectinosoma, and description of $P$. janineae sp. n. (Crustacea, Copepda, Ectinosomatidae). Zool. Scripta, 28 (3/4) : 289-303.

Hicks G.R.F. \& Schriever G. 1983. - A new genus and species of Ectinosomatidae (Copepods, Harpacticoida) based on the original material of Dr. h.c. Walter Klie. Mitt. Zool. Mus. Univ. Kiel, 2 (1) : $1-7$.

Hicks G.R.F. \& Schriever G. 1985. - Klieosoma nom. nov., a replacement name for Kliella Hicks \& Schriever, 1983 (Copepoda, Harpacticoida, Ectinosomatidae). Crustaceana, 49 (1) : 100-101.

Huys R. \& Bodin P. 1997. - First record of Acanthocephala in marine copepods. Ophelia, 46 (3) : 217-231.

Ito T. 1968. - Descriptions and records of marine Harpacticoid Copepods from Hokkaido I. J. Fac. Sci. Hokkaido Univ. Zool., 16 (3) : 369-381.

Klie W. 1949. - Harpacticoida (Cop.) an dem Bereich von Helgoland und der Kieler Bucht 1. Kieler Meeresforsch., $6: 90-128$.

Kunz H. 1974. - Harpacticoiden (Crustacea, Copepoda) aus dem Kustengrundwasser der französischen Mittelmeerküste. Zool. Scripta, $3: 257-282$.

Lang K. 1944. - Monographie der Harpacticiden (Vorläufige Mitteilung). Almqvist \& Wiksells Boktryckeri AB, Uppsala : 1-39.

Lang K. 1948. - Monographie der Harpacticiden. Nordiska Bokhandeln, Lund, A-B. : 1-1682.

Lang K. 1965. - Copepoda Harpacticoida from the Californian Pacific Coast. Kungl. Svenska Vetenskapsakad. Handl., 10 (2) : $1-560$.
Marcus A. 1967. - Harpacticoids from the rocky facies in the Black Sea : Harpacticus ponticus n. sp., Tisbe dilatata Klie, Ectinosoma melaniceps Boeck, Halectinosoma herdelongata n. n. (syn. Ectinosoma intermedium Marcus). Trav. Mus. Hist. nat. Grigore Anti$p a, 7: 29-38$.

Médioni A. \& Soyer P. 1967. - Copépodes Harpacticoides de Banyuls-sur-Mer, 6 . Nouvelles formes associées à des Bryozaires. Vie Milieu, 28 (2-A) : 317-343.

Mielke W. 1974. - Eulitorale Harpacticoidea (Copepoda) von Spitzbergen. Mikrofauna des Meeresbodens, $37: 160-210$.

Mielke W. 1979. - Interstitielle Fauna von Galapagos, XXV. Longipediidae, Canuellidae, Ectinosomatidae (Harpacticoida). $M i-$ krofauna des Meeresbodens, 77 : 294-399.

Miura Y. 1964. - Subterranean Harpacticoid Copepods from a driven well in Japan. Jap. J. Zool., 14 (2) : 133-141.

Moore C.G. 1978. - An emendation of the family name Ectinosomidae Sars to Ectinosomatidae (Copepoda, Harpacticoida). Crustaceana, 34 (1): 111.

Nicholls A.G. 1940. - Marine Harpacticoids and Cyclopoids from the shores of the St. Lawrence. Nat. cant, $66: 241-316$.

Olofsson O. 1917. - Beitrag zur Kenntnis der Harpacticiden-Familien Ectinosomidae, Canthocamptidae (Gen. Maraenobiotus) und Tachidiidae nebst Beschreibungen einiger neuen und wenig bekannten, arktischen Brackwasser- und Süsswasser-Arten. Zool. Bidrag., Uppsala, 6 : 1-39.

Rouch R. 1969. - Recherches sur les eaux souterraines. 6. Sigmatidium vandeli $\mathrm{n}$. sp., Ectinosomidae des eaux souterraines continentales. Ann. Spéléol., 24 (2) : 421-429.

Sars G.O. 1904. - Copepoda Harpacticoida. An account of the Crustacea of Norway with short descriptions and figures of all the species. Vol. 5 : 27-80, Bergen : Bergen Museum.

Sars G.O. 1920. - Copepoda supplement. Harpacticoida (continued). An account of the Crustacea of Nonway with short descriptions and figures of all the species. Vol. 7, parts III \& IV : 25-52, Bergen : Bergen Museum.

Stock J.H. \& Vaupel Klein J.C. von 1996. - Mounting media revisited : the suitability of Reyne's fluid for small crustaceans. Crustaceana, 69 (6) : 794-798.

Vervoort W. 1962. - Report on some Copepoda collected during the Melanesia Expedition of the Osaka Museum of Natural History. Publ. Seto Mar. Biol. Lab., 10 (2) : 249-326.

Wells J.B.J. 1965. - Copepoda (Crustacea) from the meiobenthos of some Scottish marine sub-littoral muds. Proc. r. Soc. Edinb., Biol., 69 (1) : 1-33.

Wells J.B.J. 1967. - The littoral Copepoda (Crustacea) of Inhaca Island, Mozambique. Trans. r. Soc. Edinb., 67 (7) : 189-358.

Wilson C.B. 1932. - The copepods of the Woods Hole region Massachusetts. Smiths. Inst. U.S. natn. Mus. Bul., 158 : 1-635. 